\title{
PENGARUH LATIHAN GERAK PINGGUL (STRETCHING) TERHADAP SKORE NYERI PINGGUL PADA LANSIA DI POSYANDU LANSIA
}

\author{
Puput Risti Kusumaningrum $^{1}$, Suyami ${ }^{2}$, Very Widiawati ${ }^{3}$ \\ ${ }^{1,2}$ STIKES Muhammadiyah Klaten \\ ${ }^{3}$ Puskesmas Wonosari, Gunung Kidul \\ Email: puputristi89@gmail.com
}

\begin{abstract}
Abstrak
Hasil wawancara dengan lansia di Posyandu pada lansia di susun Trosari menunjukkan bahwa untuk mengatasi sakit punggung, lansia biasanya pergi ke klinik untuk pemeriksaan kesehatan lansia setiap hari rabu. Lansia juga melakukan senam setiap hari untuk mendukung kebugaran fisik lansia, tetapi masih banyak lansia yang mengeluh sakit punggung yang tidak hilang telah membaik dengan menerapkan olahraga setiap hari. Tetapi latihan gerak pinggul statis belum dilakukan untuk mengurangi nyeri punggung pada lansia. Tujuan penelitian ini untuk mengetahui pengaruh pencegahan senam panggul pada nyeri skala rendah di Posyandu Lansia di Dusun Trosari, Patuk, Gunung Kidul. Desain penelitian ini menggunakan desain pre eksperimen dengan pendekatan one group pre test post test design. Teknik pengambilan sampel menggunakan teknik purposive sampling dengan jumlah sampel 10 lansia. Analisa data menggunakan paired t test. Karakteristik responden (usia rata-rata 66.30 tahun, jenis kelamin laki-laki sebanyak $70 \%$, pendidikan SD sebanyak $70 \%$ dan pekerjaan yang tidak bekerja sebanyak 40\%. Skor nyeri pinggul pada lansia sebelum diberikan pencegahan latihan gerak pinggul untuk lansia di desa Trosari dusun Patuk Gunungkidul dengan rata-rata 5.8. Skor nyeri pinggul pada lansia sesudah diberikan pencegahan latihan gerak pinggul untuk lansia di desa Trosari dusun Patuk Gunungkidul dengan rata-rata 3.3. Perbedaan skor nyeri pinggul sebelum dan sesudah diberikan pencegahan latihan gerak pinggul yaitu 2.50. Terdapat pengaruh pencegahan latihan gerak pinggul untuk lansia di desa Trosari dusun Patuk Gunungkidul.
\end{abstract}

Kata kunci: Latihan gerak pinggul (stretching exercise), skor nyeri, lansia

\begin{abstract}
The results of the interview with the elderly at the Posyandu in the elderly in Trosari hamlet show that to deal with back pain, the elderly usually go to the clinic for an elderly health check every Wednesday. Elderly also take gymnastics every day to support the physical fitness of the elderly, but there are still many elderly people who complain that their back pain that never goes away has improved even though it has been applied to exercise every day. However, Static Stretching exercises have not been carried out to reduce back pain in the elderly. The aim of the study was to determine the effect of Gymnastics Prevention of Low Pain on the Scales of Hip Pain in the Elderly at the Elderly Posyandu in Trosari Hamlet, Patuk Gunungkidul. The design of this study used Pre Experimental with the design of the One Group Pre Test-Post Test Design. The purposive sampling sampling technique is 10 people. Data analysis using paired t-test. Characteristics of respondents (age with a mean of 66.30 years, gender is male as much as 70\%, education ie elementary school as much as $70 \%$ and work that is not working as much as $40 \%$ ). Hip pain scoring in the elderly before being given the Pain Relief Gymnastics Prevention in the Elderly Village of Trosari Hamlet Patuk Gunungkidul with an average of 5.8. Scores of hip pain in the elderly after being given Elderly Pain Prevention of Lower Back Pain Exercise in Trosari Patuk Hamlet, Gunungkidul with an average of 3.3. Differences in hip pain scores before and after Low Back Pain Prevention Gymnastics were 2.50. There is the effect of Gymnastics Prevention of Low Back Pain Against Hip Pain in the Elderly at the Elderly Village of Trosari Hamlet Patuk Gunungkidul
\end{abstract}

Keywords: Stretching Exercises, Pain Scores, elderly 


\section{Pendahuluan}

Lansia merupakan suatu proses tumbuh kembang yang terjadi pada manusia, lansia itu sendiri adalah fase menurunnya kemampuan akal dan fisik, yang di mulai dengan adanya beberapa perubahan dalam hidup. Sebagaimana di ketahui, ketika manusia mencapai usia dewasa, ia mempunyai kemampuan reproduksi dan melahirkan anak. Kondisi hidup berubah, seseorang akan kehilangan tugas dan fungsi ini, dan memasuki selanjutnya, yaitu usia lanjut (Darmojo, B \& Martono, 2010). Negara Indonesia termasuk negara yang memasuki era penduduk berstruktur lanjut usia atau aging structured population karena mempunyai jumlah penduduk dengan usia 60 tahun ke atas sekitar $7,18 \%$ yang akan berdampak pada meningkatnya masalah lansia yang semakin kompleks, dari masalah kesehatan penyakit degeneratif sampai status mental lansia (Makhfudli \& Effendi, 2009). Hal ini didasari dengan dengan semakin bertambahnya usia maka kemungkinan terjadinya penurunan anatomik dan fisiologik atas organorgannya semakin besar (Boedhi, 2008). Perubahan fisiologis bervariasi pada setiap lansia, beberapa lansia tidak mampu melakukan aktivitas atau aktivitasnya terbatas karena adanya masalah fisik, emosional, atau sosial yang membuat lansia merasa sakit. Dengan munculnya rasa nyeri yang dirasakan oleh lansia ini maka akan mengakibatkan lansia tidak produktif terutama dalam hal aktivitas maupun keterbatasan dalam merawat dirinya secara mandiri (Maryam, R.S, 2010).

Berdasarkan studi pendahuluan pada bulan di posyandu Lansia Trosari Gunungkidul, didapat keseluruhan lansia berjumlah 116 orang. Hasil wawancara dengan lansia di posyandu lansia dusun Trosari didapatkan data bahwa untuk mengatasi nyeri pinggul biasanya lansia memeriksakan diri di klinik swasta atau ke Puskesmas dengan mengikuti senam setiap hari rabu/hari yang ditentukan kembali dan dilakukan sebulan 2 kali (Prolanis) untuk menunjang kebugaran jasmani lansia, akan tetapi masih banyak lansia yang mengeluh akan nyeri pinggulnya yang tak kunjung berangsur membaik walau sudah diberlakukan senam. Namun belum pernah dilakukan latihan gerak Stretching untuk mengurangi nyeri pinggul pada lansia.

$$
\text { Penurunan fleksibilitas }
$$

merupakan salah satu yang dapat menyebabkan nyeri, nyeri pada daerah sekitar vertebrae dikarenakan fleksibilitasnya mulai berkurang (Pudjiastuti, 2013). Fleksibilitas merupakan kemampuan otot untuk memanjang/mengulur semaksimal mungkin sehingga tubuh dapat bergerak dengan bebas tanpa adanya rasa tidak nyaman/nyeri (Ilyas, 2016).

Fleksibilitas

vertebrae merupakan kemampuan jaringan disekitar persendian atau kemampuan persendian pada bagian vertebrae untuk bergerak bebas dan nyaman hingga mencapai Range Of Motion (ROM) yang maksimal. Fleksibilitas sendi merupakan kemampuan jaringan disekitar persendian untuk menghasilkan peregangan tanpa adanya gangguan dan komunikasi rileksasi (Astuti, 2010).

Nyeri Punggung Bawah (NPB) /nyeri pinggul merupakan suatu sindroma klinis yang ditandai dengan adanya rasa nyeri atau sensasi tidak nyaman disepanjang daerah tulang belakang bagian bawah (Yulitania, 2015). Kondisi ini sering menjadi kronis, menetap, atau kadang berulang kali serta tidak boleh dipandang sebelah mata. Menjadi tua (menua) merupakan suatu proses menghilangnya kemampuan jaringan untuk memperbaiki diri secara perlahanlahan dan mempertahankan struktur dan fungsi normalnya (Fatmah, 2010).

Terdapat beberapa tindakan untuk menurangi rasa nyeri pada lansia, 
tindakan-tindakan tersebut mencakup tindakan non farmakologi dan tindakan farmakologi. Dalam beberapa kasus nyeri yang sifatnya ringan, tindakan non farmakologi adalah yang paling utama, sedangkan tindakan farmakologi dipersiapkan untuk mengantisipasi perkembangan nyeri. Sebagai contoh untuk tindakan non farmakologi adalah pijat, senam, acupressure, kompres hangat, bedrest. Salah satu tindakan yang dapat dilakukan peneliti untuk mengatasi masalah nyeri pinggul tersebut yaitu dengan melakukan terapi latihan Stretching, selain dapat menurunkan nyeri juga dapat mengembalikan kelenturan otot-otot yang mengalami kekakuan (Mujianto., 2013). Latihan gerak pinggul yang diberikan kepada lansia dalam penelitian ini adalah latihan gerak pencegahan nyeri pinggul yang di ciptakan oleh dr.Yuda Turana. Latihan gerak pencegahan nyeri pinggul adalah satu bagian dari rumpun senam, sesuai dengan dengan istilahnya, maka gerakangerakan pada latihan senam tersebut bertujuan untuk mencegah ataupun mengurangi terjadinya nyeri pada bagian pinggul yang sering terjadi pada lansia pada umumnya. Gerakan senam difokuskan pada daerah sekitar pinggul dan adanya gerakan penguluran atau strech pada otot-otot daerah tersebut.
Latihan senam dan aktivitas fisik pada lansia dapat mempertahankan kenormalan pergerakan persendian, tonus otot dan mengurangi masalah fleksibilitas (Walker, 2011).

\section{Metode Penelitian}

Desain penelitian ini menggunakan Pre Eksperimental dengan rancangan One Group Pre Test-Post Test Design, Populasi yang digunakan dalam penelitian ini adalah semua lansia di Posyandu Lansia Dusun Trosari Patuk Gunungkidul sebanyak 116 orang.

Pengambilan sampel dalam penelitian ini dilakukan dengan metode purposive sampling. analisa bivariat dilakukan uji normalitas menggunakan Shapiro Wilks karena jumlah repsonden kurang dari 50. Hasil uji normalitas didapatkan nilai $p$ value $=0,575$ dan postest dengan $p$ value $=0,115$ jadi data berdistribusi normal. Hasil uji normalitas $p$ value $>0,05$ jadi data berdistribusi normal, sehingga uji hipotesis menggunakan uji paired $t$-test.

Penelitian ini peneliti menjelaskan tentang jalannya penelitian dan menjunjung tinggi etika penelitian yang meliputi respect for human dignity, respect for privacy and confidentiallity, respect for justice inclusiveness and balancing harm and benefits.

\section{Hasil Penelitian}

1. Karakteristik Responden

a. Umur

Tabel 1

Rerata Umur Responden di Posyandu Lansia $(n=10)$

\begin{tabular}{llllll}
\hline & $\mathrm{N}$ & Min & Maks & Mean & SD \\
\hline Umur & 10 & 60 & 70 & 66,30 & 3,26 \\
\hline
\end{tabular}

Berdasarkan tabel 1 diketahui bahwa rerata umur responden $66,30 \pm 3,26$ tahun. 
b. Pendidikan

Tabel 2

Distribusi Frekuensi Karakteristik responden di Posyandu Lansia (n=10)

\begin{tabular}{cccc}
\hline No & Karakteristik & Frekuensi & $\%$ \\
\hline 1 & Pendidikan & 7 & \\
& SD & 1 & 70 \\
& SMP & 2 & 10 \\
& SMA & 0 & 20 \\
PT & & 0 \\
\hline 2 & Jenis Kelamin & 7 & 70 \\
Laki-laki & 3 & 30 \\
\hline 3 & Perempuan & & \\
& Pekerjaan & 4 & 40 \\
& Tidak Bekerja & 1 & 10 \\
& Swasta & 4 & 40 \\
& Buruh & 1 & 10 \\
\hline & Wiraswasta & 10 & 100 \\
\hline
\end{tabular}

Berdasarkan tabel 2 diketahui bahwa paling banyak pendidikan responden adalah SD sebanyak 7 orang (70\%). Sebagian besar jenis kelamin responden adalah laki-laki sebanyak 7 orang (70\%). Sebagian besar responden tidak bekerja sebanyak 4 orang $(40 \%)$ dan buruh sebanyak 4 orang $(40 \%)$.

2. Nyeri Sebelum dan Sesudah Diberikan latihan Stretching

Tabel 3

Rerata Nyeri responden di Posyandu Lansia $(n=10)$

\begin{tabular}{cccccc}
\hline Nyeri & $\mathrm{n}$ & Min & Maks & Mean & SD \\
\hline Sebelum & 10 & 4 & 8 & 5,8 & 1,31 \\
Nyeri Setelah & 10 & 3 & 4 & 3,3 & 0,67 \\
\hline
\end{tabular}

Berdasarkan tabel 3 diketahui bahwa rerata nyeri sebelum diberikan latihan

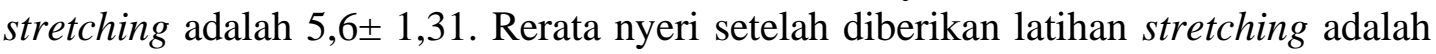
$3,3 \pm 0,67$, hal ini menunjukkan terjadinya penurunan nyeri.

3. Pengaruh Latihan Stretching terhadap Nyeri

Tabel 4

Hasil Uji Normalitas

\begin{tabular}{ll}
\hline & $P$ value \\
\hline Pretest & 0,575 \\
Postest & 0,115
\end{tabular}

Berdasarkan tabel 4 menunjukkan bahwa sebelum dilakukan uji bivariat, dilakukan uji normalitas data menggunakan Shapiro Wilks, hasil uji normalitas data, adalah $p$ value 0,575 dan $p$ value 0,115 yang berarti $p$ value $>0,05$. Hal ini dapat disimpulkan data tidak berdistribusi tidak normal. Analisis yang digunakan adalah uji pired t-test. 
Tabel 5

Pengaruh Latihan Stretching terhadap skore nyeri

\begin{tabular}{lll}
\hline Kelompok & Mean & P value \\
\hline Pretest skore nyeri $(\mathrm{n}=10)$ & 9,50 & 0,000 \\
Postest skore nyeri $(\mathrm{n}=10)$ & & \\
\hline
\end{tabular}

Berdasarkan tabel 5 diketahui bahwa nilai nilai $p$ value $=0,000(\alpha<0,05)$ hal ini berarti ada pengaruh terapi stretching terhadap skore nyeri.

\section{PEMBAHASAN}

A. Analisa Univariat

1. Karakteristik Responden

a. Umur

Hasil penelitian
menunjukkan rerata umur lansia adalah 66,30 tahun. Pada penelitian ini menunjukkan bahwa responden dengan usia terendah adalah 55 tahun dan usia tertinggi adalah 65 tahun. Usia responden yang paling banyak mengalami nyeri adalah usia early old age (5565 tahun). Karena seseorang yang sudah mencapai usia lanjut akan mengalami proses penuaan. Dimana terjadi penurunan fungsi organ didalam tubuh dan fungsi sel untuk beregenerasi, sehingga akan memicu perubahan pada proses menua, salah satunya adalah perubahan pada sistem muskuloskeletal (Nugroho, 2008).

Usia mempunyai peranan yang penting dalam mempersepsikan dan mengekspresikan rasa nyeri. Pasien dewasa muda memiliki respon yang berbeda terhadap nyeri dibandingkan pada lansia. Lansia membutuhkan intensitas lebih tinggi dari rangsangan nyeri dibandingkan orang usia muda. Pada pasien dewasa tua menganggap bahwa nyeri merupakan komponen alamiah yang harus mereka terima dari respon penuaan, sehingga keluhan sering diabaikan. Biasanya kondisi nyeri hebat pada dewasa muda dapat dirasakan sebagai keluhan ringan pada dewasa tua. Penjelasan di atas memberikan gambaran pada penelitian ini bahwa dapat disimpulkan intensitas nyeri terkait dengan usia didominasi atau lebih banyak disebabkan oleh kesalahan persepsi, emosi yang labil, prasangka, dan sikap defensif, sehingga individu menutupi sensasi nyeri yang sebenarnya dirasakan(Padila, 2013).

b. Pendidikan

Hasil penelitian menunjukkan sebagian besar adalah SD sebanyak 70\%. Berhubungan dengan mekanisme koping nyeri pada responden bahwa pendidikan bukan merupakan faktor yang mempengaruhi nyeri. Hal ini sejalan dengan penelitian yang dilakukan oleh Ramadini, Indri dan Lestari (2017), tingkat pendidikan seseorang berpengaruh terhadap pengetahuan sehingga mempengaruhi gaya hidup seseorang. Pendidikan yang masih rendah dan informasi yang kurang mempengaruhi pengetahuan dan pemahaman tentang nyeri sehingga 
berpengaruh terhadap sikap dan kemampuan melakukan pencegahan maupun penanganan pertama faktor nyeri .

Pendidikan merupakan proses perubahan sikap dan tingkah laku seseorang dalam usaha mendewasakan diri manusia melalui upaya pengajaran dan latihan. Hal tersebut berhubungan dengan strategi koping yaitu konsekuensi masing-masing individu untuk menilai suatu keadaan (Irianto, 2014).

\section{c. Jenis Kelamin}

Hasil penelitian ini menunjukkan bahwa sebagian besar responden dengan jenis kelamin laki-laki sebanyak 70\%. Hasil penelitian menunjukan responden dengan jenis kelamin laki-laki lebih banyak daripada responden dengan jenis kelamin perempuan. Jenis kelamin merupakan salah satu faktor yang mempengaruhi nyeri. Hal ini terjadi karena secara fisiologis, kemampuan otot perempuan memang lebih rendah dari pada laki-laki. Kekuatan otot perempuan hanya dua pertiga dari kekuatan otot laki-laki, sehingga daya tahan otot lakilaki pun lebih tinggi dibandingkan dengan perempuan. Rerata kekuatan otot perempuan kurang lebih hanya $60 \%$ dari kekuatan otot laki-laki, khususnya untuk otot lengan, punggung dan kaki (Pendiarto, 2017). d. Pekerjaan

Berdasarkan tabel 2 diketahui bahwa mayoritas pekerjaan responden adalah buruh sebanyak 4 orang (40\%). Hal ini sejalan dengan penelitian yang dilakukan oleh Ramadini, Indri dan Lestari ( 2017) adanya perbedaan pekerjaan menyebabkan kesenjangan rutinitas yang berbeda. Pekerjaan yang membutuhkan aktifitas sedang sampai tinggi dan dilakukan secara teratur dapat mencegah terjadinya nyeri.

Faktor pekerjaan dilaporkan berkontribusi pada beberapa penyakit otot rangka. Pada tahun 2013 WHO memperkirakan prevalensi gangguan otot rangka mencapai hampir $60 \%$ dari semua penyakit akibat kerja. Berbagai bagian tubuh dapat mengalami gangguan otot rangka dengan lokasi tersering pada bagian punggung bawah (Anggraeni, 2015).

2. Nyeri Sebelum Diberikan latihan gerak pinggul (Stretching)

Hasil penelitian menunjukkan bahwa sebelum diberikan latihan stretching dengan rerata skore nyeri 5,8 sedangkan setelah diberikan terapi strestching didapatkan rerata skore nyeri 3,3. Hasil ini menunjukkan terjadi penurunan skore nyeri sesudah diberikan latihan stretching.

Nyeri pinggul dapat dialami oleh siapa saja, namun berdasar faktor etiologi tertentu nyeri pinggul sering dijumpai pada usia yang lebih tua (Sa'adah, 2012). Nyeri pinggul merupakan rasa nyeri, ngilu, pegal yang terjadi di 
daerah pinggul. Nyeri pinggul bukanlah diagnosis tapi hanya gejala akibat dari penyebab yang sangat beragam (Muhith, A, \& Yasma, A 2014). Nyeri pinggul dapat dirasakan sebagai akibat dari tarikan/sprain (cedera pada ligamen sendi), cedera (kecelakaan atau saat berolahraga, kerusakan otot, patah tulang akibat osteoporosis, penyakit peradangan seperti arthritis reumatoid, kanker (misalnya kanker prostat dan pankreas), infeksi kandung kemih dan infeksi tulang punggung seperti tuberkulosis (Aishii, 2011) .

Nyeri pinggul dapat dicetuskan oleh beberapa faktor seperti postur tubuh yang buruk, kurang olahraga, berdiri atau membungkuk dalam waktu yang lama, duduk dikursi yang tidak memiliki sandaran panggul baik, tidur pada kasur yang tidak sesuai, mengemudi dalam waktu yang lama, kegemukan, hamil, dan mengangkat, menjinjing, mendorong atau menarik beban yang terlalu berat (Bull, E., 2007).

Nyeri pinggul yang dialami responden dapat disebabkan karena postur tubuh yang buruk dan duduk dan jongkok dalam waktu yang lama. Hal ini terlihat dari kegiatan yang dilakukan seperti adanya kegaiatan bimbingan rohani, bimbingan ketrampilan, bimbingan sosial dan bimbingan kebersihan. Kegiatan tersebut menuntut lansia untuk seringkali duduk dalam waktu yang lama. Hal ini dapat menyebabkan ketegangan otot yang meningkat sehingga muncul rasa nyeri terutama pada punggung bagian bawah. Nyeri pinggul dapat menimbulkan keterbatasan fungsi yaitu gangguan saat dari keadaan duduk, saat membungkuk, saat duduk atau berdiri lama dan berjalan (Kusharyadi, 2010).

Hasil penelitian menunjukkan bahwa tingkat nyeri pinggul pada lansia sebelum diberikan sesudah diberikan latihan gerak pinggul (stretching) sebagian besar lansia mengalami nyeri sedang dan dari lansia yang mengalami nyeri sedang setelah diberikan latihan gerak pinggul (stretching) menjadi menurun sebagian besar lansia mengalami nyeri ringan. Dengan demikian pemberian latihan gerak pinggul (stretching) terdapat pengaruh yang signifikan untuk menurunkan tingkat nyeri pinggul pada lansia.

Sa'adah (2012) mengatakan bahwa orang yang menyempatkan melakukan olah tubuh minimal 30 menit setiap hari dapat memberikan keuntungan yang berlipat dan itu akan bertahan walaupun usia bertambah. Faktor dari lansia dalam melakukan peregangan (stretching) adalah lansia dengan indeks $\mathrm{Katz} \mathrm{A}$ dan keinginan lansia untuk terus melakukan latihan adalah faktor kebersamaan sehingga dalam pelaksanaan lansia mengalami rileks dan perasaan senang. Pemberian peregangan (stretching) merupakan tindakan non farmakologi yang dilakukan sebanyak $3 x$ seminggu selama 2 minggu.

Stretching adalah penghubung penting antara kehidupan statis dan kehidupan aktif. Stretching dapat membuat otot tetap lentur, mencegah cedera yang umum terjadi, membuat seseorang siap 
bergerak, dan membantu seseorang berlaih dari aktivitas kurang gerak ke aktivitas banyak gerak tanpa menimbulkan ketegangan (Andeson, 2010). Dengan melakukan Stretching dapat meregangkan otot-otot ekstensor punggung bawah, karena semakin otot itu relaks dan tidak tegang maka otot tersebut dapat bergerak dengan penuh tanpa adanya rasa nyeri dan spasme. Sehingga responden mengalami penurunan tingkat nyeri terutama nyeri pinggul.

\section{B. Analisa Bivariat}

Hasil analisis uji statistik Berdasarkan tabel 5 diketahui bahwa nilai $p$ value $=0,000(\alpha<0,05)$ hal ini berarti ada pengaruh terapi stretching terhadap skore nyeri. Respon nyeri seseorang dapat dipengaruhi oleh beberapa faktor yaitu usia, jenis kelamin, kebudayaan, perhatian, makna nyeri, ansietas, mekanisme koping, keletihan, pengalaman sebelumnya,serta dukungan keluarga dan sosial (Zakiyah, 2015).

Penurunan tingkat nyeri pinggul pada lansia sebagian besar tidak mengalami penurunan tingkat nyeri secara signifikan. Hal ini dipengaruhi oleh jenis kelamin yang hampir seluruhnya adalah perempuan dengan rasa sensitif yang tinggi bila mengalami nyeri, adanya kegiatankegiatan kemanusiaan di panti yang mengharuskan untuk duduk dan aktivitas sehari-hari yang dilakukan lansia.

Sikap tubuh yang salah, seperti duduk terlalu lama seringkali mengalami perlambatan peredaran darah mereka yang bawah. Kelelahan dapat timbul sebagai akibat terlalu banyaknya zat-zat yang seharusnya dibuang tetapi tetap terkumpul, sedangkan otot-otot kurang mendapatkan makanan. Keletihan otot biasanya disebabkan oleh terlampau banyak asam laktat terkumpul dalam otot- otot (Lukman \& Ningsih, 2012). Nyeri pinggul menyerang daerah pusat tubuh yang menjadi pusat gerakan yang dekat dengan organ-organ penting tubuh. Apabila masih terdapat nyeri pada pinggul berarti gerakan pada lansia masih kurang efektif dan kelenturan ototnya masih kurang. Hal ini dibuktikan dengan masih terasa nyeri atau nyeri tidak berkurang, selain itu juga karena terjadi proses degenerasi. Pemberian static stretching ini masih belum optimal karena faktor usia lansia, dan latihan ini hanya dilaksanakan $3 x$ seminggu selama 2 minggu. Sebaiknya lansia bisa melaksanakan static stretching ini sendiri dan dapat dilakukan secara rutin di panti (Anggraeni, 2015).

Latihan stretching ini merupakan intervensi yang termasuk dalam pendekatan non farmakologi misalnya dengan memberi latihan yang tepat (spesifik), dengan demikian latihan stretching dapat membantu menurunkan kelemahan, menghilangkan stres, meningkatkan kekuatan otot. Latihan ini juga dapat meningkatkan sirkulasi darah dan meningkatkan oksigenasi sel. Dengan cara itu latihan dapat mengurangi gejala kekurangan oksigen sel yang dapat menyebabkan peningkatan asam laktat yang dapat menimbulkan nyeri. Duduk dalam waktu yang lama adalah penyebab terbesar sakit di bagian pinggul. Perlu dilakukan stretching untuk menggerakan otot pinggul dan agar peredaran darah lancar. Cara ini berguna agar lansia terhindar dari masalah nyeri pinggul (Andeson, 2010). Gerakan stretching yang diaplikasikan pada lansia adalah gerakan yang berfokus pada leher, tangan, pinggang dan kaki yang berfungsi untuk melenturkan otot-otot 
bagian yang difokuskan. Stretching pada otot-otot yang dilakukan dalam 10 gerakan secara bertahap, setiap gerakan dilakukan penahanan selama 10-15 detik untuk merasakan adanya tarikan pada otot-otot yang difokuskan dan melakukan pengulangan dua kali untuk setiap gerakan. Gerakan peregangan ini sangat sederhana dan mudah dilakukan. Seperti yang diungkapkan oleh Nelson, A.G \& Kokkonen (2007) bahwa peregangan dapat dilakukan hampir di segala tempat dan kapan saja. Tidak memerlukan peralatan khusus, tidak ada pakaian khusus, dan tidak ada ketrampilan khusus.

$$
\text { Bogduk (2005) dalam }
$$

(Novikasari, 2013) menyebutkan penerapan teknik static stretching adalah bahan kontraksi isotonik yang dilakukan saat stretching dari otot yang mengalami pemendekan akan menghasilkan otot memanjang secara maksimal tanpa perlawanan. Pemberian static stretching yang dilakukan secara perlahan juga akan menghasilkan peregangan pada sarkomer sehingga peregangan akan mengembalikan elastisitas sarkomer yang terganggu. Pada saat melakukan static stretching otot antagonis (kelompok otot pada sisi yang tidak di regangkan) dan otot agonis (otot yang diregangkan) keduanya relaks. Secara perlahan dan lembut, gerakan tubuh meningkatkan tekanan pada grup otot yang akan diregangkan. Beberapa bentuk adaptasi yang dapat diperoleh dari aktivitas peregangan yang biasa di lakukan (reguler) dengan teknik yang benar adalah ketika otot secara tibatiba diregangkan, maka pertama-tama akan timbul stretch reflex, selanjutnya otot yang diregangkan akan berkontraksi.

Selama melakukan latihan, titik kritis pada stretch reflex tersebut dapat muncul kembali pada tingkatan latihan selanjutnya. Konsekuensinya, otot-otot akan lebih lama rileks selama stretching. Selama kurun waktu bertambahnya peregangan, sarungsarung (lapisan) fascial yang menyelubungi otot-otot akan mengalami perubahan panjang semipermanen. Sarung - sarung ini meliputi epymisium, endomysium, dan perimysium. Jaringan-jaringan tambahan yang beradaptasi dengan stretching akan berubah fungsinya menjadi tendons, ligament, fascia dan jaringan scar. Latihan peregangan diyakini dapat menstimulasikan produksi dari peyimpanan suatu bahan yang menyerupai gel yang disebut glycoaminoglycans (GAGs). GAGs tersebut, bersama-sama dengan air dan asam hyaluron, melumasi dan menjaga jarak kritis antara serat-serat jaringan penghubung dalam tubuh seseorang (Maryam, R.S, 2010).

\section{Simpulan}

Terapi stretching berpengaruh terhadap skore nyeri dengan $p$ value $=$ 0,000. Latihan stretching ini merupakan intervensi yang termasuk dalam pendekatan non farmakologi misalnya dengan memberi latihan yang tepat (spesifik), dengan demikian latihan dapat membantu menurunkan kelemahan, menghilangkan stres, meningkatkan kekuatan otot. Latihan ini juga dapat meningkatkan sirkulasi darah dan meningkatkan oksigenasi sel.

\section{Referensi}

Aishii. (2011). Pengaruh Pemberian Stretching pada Otot Gastroknemius dan Otot Hamsting Terhadap Keseimbangan Dinamis pada Lansia.

Andeson, B. (2010). Stretching. Jakarta : Serambi Ilmu Semesta.

Anggraeni, R. R. (2015). Nyeri Punggung Bawah pada Pekerja Bagian Kniitting Gantung. Jakarta: PT. 
Royal Korindah.

Astuti, V. W. (2010). Hubungan Dukungan Keluarga dengan Tingkat Depresi pada Lansia di Posyandu Sejahtera GBI Setia Bakti Kediri V, $3(2), 78-84$.

Boedhi, D. (2008). Geriatri (Ilmu Kesehatan Usia Lanjut), Edisi 4. Jakarta : Balai. Penerbit FKUI.

Bull, E., dan G. A. (2007). Simple Guide: Nyeri Punggung. Dialihbahasakan oleh Juwalita Surapsari. (A. Editor: Astikawati, Rina dan Safitri, Ed.). Jakarta: Penerbit Erlangga.

Darmojo, B \& Martono, H. (2010). Geriatri Ilmu Kesehatan Usia Lanjut. Ed-4. Jakarta : FKUI.

Fatmah. (2010). Gizi Usia Lanjut. Jakarta : Erlangga.

Ilyas, F. R. (2016). Hubungan Antara Fleksibilitas Dengan Delayed Onset Muscle Soreness Pada Mahasiswa Ekstrakulikuler Karate Universitas Hasanuddin.

Irianto, K. (2014). Seksologi Kesehatan. Bandung: ALFABETA.

Kusharyadi. (2010). Asuhan Keperawatan Pada Klien Usia Lanjut. Jakarta: Salemba Medika.

Lukman \& Ningsih, N. (2012). Asuhan Keperawatan Pada Klien Dengan Gangguan Sistem Muskuloskeletal. Jakarta : Salemba Medika.

Makhfudli \& Effendi, F. (2009). Keperawatan kesehatan komunitas. Jakarta: Salemba Medika.

Maryam, R.S, D. (2010). Buku Saku Asuhan Keperawatan Pada Lansia. Jakarta : CV. Trans Info Media.

Muhith, A, \& Yasma, A, N. (2014). Pengaruh Terapi William Flexion Exercise Terhadap Nyeri Punggung Bawah Pada Lansia Di Panti Werdha Mojopahit Mojokerto.

Mujianto. (2013). Cara Cepat Mengatasi 10 Besar Kasus Muskuloskeletal
Dalam Praktik Klinik Fisioterapi. Jakarta : CV. TransInfo Media.

Nelson, A.G \& Kokkonen, J. (2007). Stretching Anatomy. United States: Human Kinetic.

Novikasari, N. (2013). Pengaruh Pemberian Static Stretching terhadap Peningkatan Fleksibilitas Lumbal Pada Lanjut Usia di Desa Guli Kabupaten Boyolali.

Nugroho, W. (2008). Keperawatan Gerontik \& Geriatrik. Jakarta : EGC.

Padila. (2013). Buku Ajar Keperawatan Gerontik. Yogyakarta: Nuha Medika.

Pendiarto, R. P. (2017). Pengaruh Terapi Static Stretching Terhadap Nyeri Punggung Pada Lnsia di Balai Pelayanan Sosial Tresna Werdha Unit Abiyoso Yogyokarta.

Pudjiastuti, S. S. (2013). Fisioterapi Pada Lansia. Jakarta: Buku Kedokteran EGC.

Ramadini, Indri dan Lestari, S. (2017). Hubungan aktivitas fisik dan stress dengan nyeri dada pasien penyakit jantung koroner, 2(3).

Sa'adah, H. D. (2012). Pengaruh Latihan Fleksi William (Stretching) terhadap Tingkat Nyeri Punggung Bawah pada Lansia di Posyandu Lansia RW 2 Desa Kedungkandang Malang, (1997), 56-61.

Walker, B. (2011). Ultimate Guide to Stretching \& Flexibility. Ed-3. United States : Injury Fix.

Yulitania, D. D. (2015). Perbedaan Pengaruh Peregangan Dan William Flexion Exercise Terhadap Nyeri Punggung Bawah Non Spesifik Pada Pemetik Teh Di Perkebunan Teh Jamus.

Zakiyah, A. (2015). Nyeri: Konsep dan Penatalaksanaan dalam Praktik Keperawatan Berbasis Bukti. Jakarta : Salemba Medika. 